\title{
Pseudo-Pleurococcus, Nov. gen.
}

\author{
BY \\ JULIA W. SNOW, Ph.D. \\ With Plate $\mathbf{X I}$.
}

PLEUROCOCCUS VULGARIS, though one of the most common of all Algae and one that has received much attention, is also one about which there still exist widely differing views.

Klebs (5), Artari (1), and Gay (4) hold that Pleurococcus vulgaris is a perfectly constant form which reproduces only by means of vegetative division, and either exists as single cells or forms small cell-complexes more or less quadrangular in shape. This, according to these authors, is accidental, and division in other directions soon occurs, producing the normal small complexes.

Chodat (3), on the other hand, states that 'Pleurococcus in the various conditions of its evolution may develop branches, filaments, sporangia with zoospores, gametes, and spores.' And under the name of Pleurococcus he would include 'not only the common form without a pyrenoid, but also the similar one with a pyrenoid ( $P l$. simplex, Artari), as well as such very different forms as Cystococcus and Protococcus vulgaris.' Further, he regards Pleurococcus as one of the Chaetophoraceae in a stage of degradation, owing to its existence as a Lichen-gonidium.

[Annals of Botany, Vol. XIII. No. L. June, I899.] 
That certain unicellular organisms are but phases of some higher Algae, assumed under some special condition, is now well recognized, and more and more is it evident that external conditions affect external characteristics. But it has been the result of my observation in all such cases, that the internal characteristics of a cell remain the same, however much external appearance may vary. Never have I observed the least variation in the internal organization of any species, although I have kept numerous unicellular and polymorphic forms in pure culture for many months at a time. With this in mind it is difficult to understand how Chodat can include under one species cells with and without a pyrenoid, and with either a parietal or a stellate chromatophore, as he does in the case of Pleurococcus vulgaris.

The view held by Klebs, Artari, and Gay with regard to Pleurococcus vulgaris is undoubtedly correct, as I have been able to verify in Klebs' own cultures and in numerous cultures of my own. There are, however, forms similar to that described by Chodat (2), which in their unicellular condition cannot readily be distinguished from Pleurococcus vulgaris, and which, under the influence of moisture, do produce filaments. But a close comparison of these forms shows differences which would prevent them from being classified with Pleurococcus vulgaris. Whereas in the latter species the chromatophore lines the whole inner surface of the membrane, in the corresponding small cell-complexes of the other forms the chromatophore is found in only a portion of the cell. Pleurococcus vulgaris, also, contains no pyrenoid, while in the filamentous forms which have come to my notice a pyrenoid is present. Chodat, however, found none in the form he studied.

One significant difference between these filamentous forms and Pleurococcus vulgaris is the response to cultivation. The latter form lives but a short time in Knop's solution of various concentrations, but under the very same conditions the forms which produce filaments grow well for any length of time.

In referring to this form described by Chodat (2), Klebs regards it as a Stigeoclonium which normally exists in a 
protococcoid condition, and he believes it should be classified as such. Zoospores, however, have not been observed to be formed from the filaments, and on this account it would seem best to separate these forms from both Pleurococcus and Stigeoclonium and to create a new genus. As they resemble Pleurococcus so closely they might appropriately be called Pseudo-Pleurococcus. A description of two of these forms will here be given.

\section{Pseudo-Pleurococcus botryoides, Nov. sp.}

This was found on the bark of a tree near Ann Arbor, Michigan, in December '97, and formed a thick, dark-green, pulverulent covering, quite like that formed by Pleurococcus vulgaris. Microscopical examination showed it to consist of single cells and of parenchymatous masses varying in size from two cells up to clusters large enough to be easily distinguished by the naked eye (Figs. I-6). The cells measure $6.5-7.8 \mu$ in diameter. The chromatophore lines the membrane, but presents a somewhat irregular opening on one side. Opposite this opening lies the pyrenoid. The membrane is thin and gives the reaction for cellulose with iodine and sulphuric acid. The nucleus is single and lies near the centre.

Material directly from the bark was placed under cultivation in Knop's solution of various concentrations, and on agar mixed with the same solution. All of these media possessed more moisture than was present on the bark, and the result was that all the cultures began immediately to produce filaments, one arising from almost every superficial cell (Figs. $7,8, \mathrm{I} 4, \mathrm{I} 5)$. Growth of the filaments continued for some time in all media alike; but after the Alga became accustomed to the stimulating effects of the moisture, development varied according to the condition. On agar, and in Knop's solution of $.4 \%$ and $\mathrm{I} \%$, the filaments gradually began to assume the parenchymatous form; while in weaker solutions, such as $\cdot 1 \%$, the filaments continued to grow and to branch, until 
large radiating clusters were produced fully $1-2 \mathrm{~mm}$. in diameter. A small one of these is shown in Fig. I6.

The transformation from the filaments to the parenchymatous masses began by longitudinal division taking place in the filaments (Fig. I3), when both longitudinal and transverse division continued until all semblance of a filament was lost. In $\cdot 4 \%$ Knop's solution, if at any time during the transformation fresh nutritive solution, or even water, were added, the process was interrupted and new filaments were sent out from the rounded cells. In time these filaments also began to become parenchymatous; but each time that fresh liquid was added filaments were produced, so that by adding liquid and then allowing the filaments to become parenchymatous, the shape and the nature of the development could, within certain limits, be controlled.

Agar-cultures with little moisture seemed to reproduce best the conditions in nature. At first filaments were formed, but these soon passed into parenchymatous clusters of cells which afterwards became more or less disorganized; the cells became rounded and the connexion became less intimate, so that, by disturbance, disintegration of the clusters occurred; usually, however, two, four, or more cells remained united.

The development can be traced from a single cell. If a cell from bark be placed in liquid it will develop directly into a filament (Figs. 7,8 ). In a $4 \%$ Knop's solution, however, a cell which had already become accustomed to this solution was seen to develop directly into a parenchymatous mass with a tendency to disintegration (Figs. 9-12), and one instance was noticed under similar conditions where cells separated directly after division, thus causing the Alga to remain in a unicellular condition.

Strong nutritive solutions and also weaker solutions, providing the Alga has existed in these for some time, produce the same effect as existence in the atmosphere; that is, the parenchymatous and unicellular conditions occur, but change from the atmosphere to liquid always produces filaments.

In general we can say that when the form exists in a medium 
where there is little moisture, the Pleurococcus-like condition is produced, the cells being either single or in small clusters; but when subjected to much moisture filaments are produced. This would seem to hold true also in nature, for even among the parenchymatous masses of cells taken from bark the form of the masses often suggested filaments, which had possibly been produced during a wet period, and afterwards transformed to the parenchymatous condition during a following dry season.

Whether we can regard this as a degenerate form of Alga which reverts to a filamentous form when placed in liquid media, is difficult to say. Might we not with equal right regard the filaments as a higher form which is being evolved from the lower by being placed under more favourable conditions?

Pseudo-Pleurococcus vulgaris, Nov. sp.

This form is characterized in its aerial existence by smaller cell-complexes than the preceding species, and in liquid media by branching less profusely (Figs. I7, I 8). The mode of branching also is different. Instead of branches arising from any cell along the filament, their origin is terminal, two growing-points being developed at the apical cell.

The chromatophore does not occupy the whole cell, but lines only a portion of the cell-wall; and in the filamentous form often more than one chromatophore is present. The single cells are $6.5 \mu$ in diameter; a pyrenoid is present; no blue colour was produced in the membrane either with chlor-iodide of zinc or with iodine and sulphuric acid.

The conditions governing form in this species are the same as in the preceding. In liquid culture-media filaments were produced, while on agar with Knop's solution total disintegration took place. The transformation from the filamentous to the unicellular condition also began by longitudinal division occurring in the filaments (Fig. I9). The process of disintegration, however, took place more rapidly and was carried farther than in the first species, for, within three weeks' time, 
a filamentous cluster transferred to agar changed completely to the unicellular condition.

This form resembles Pleurococcus vulgaris greatly. It also resembles the illustrations of the form described by Chodat; but as this contains a pyrenoid, and none was found in the species he studied, it cannot be the same.

If these filamentous forms be regarded as a genus separate from Pleurococcus, the genus would be characterized as follows :-

Pseudo-Pleurococcus, Nov. gen.

Thallus, in the atmosphere either unicellular or forming parenchymatous masses of cells of various size; in liquid media filamentous. Cells $6 \cdot 5-8 \mu$ in diameter. Chromatophore parietal, but not completely lining the membrane. Nucleus single.

\section{Pseudo-Pleurococcus botryoides, Nov. sp.}

In atmosphere occurring as single cells, or forming dense clusters of various size; in liquid media profusely branched, the branches arising laterally from the filaments. Cells $6.5-7.8 \mu$ in diameter. Chromatophore in the single cells reduced, pyrenoid present. On bark of trees near Ann Arbor, Michigan.

\section{Pseudo-Pleurococcus vulgaris, Nov. sp.}

In atmosphere occurring as single cells, or in cell-complexes of four or multiples of four; in liquid media branched, but not profusely so, the branches originating by the division of the apex of a terminal cell. Chromatophores line but a portion of the membrane in each cell of the filament; often two or more occur in a single cell. Diameter of cells $6.5 \mu$; pyrenoid present in the chromatophore. On bark of trees in Basel, Switzerland. 


\section{LITERATURE.}

1. Artari, A.: Untersuchungen über Entwickelung und Systematik einiger Protococcoideen; Inaug. Diss., Moskau, $189^{2}$.

2. Chodat, R. : Matériaux pour servir à l'histoire des Protococcoidées; Bull, de l'Herbier Boissier, I894.

3. Chodat, R.: On the Polymorphism of the Green Algae and the Principles of their Evolution; Annals of Botany, Vol. XI, No. 4I, I897.

4. Gay, Fr.: Recherches sur le développement et la classification de quelques Algues vertes ; Paris, I 89 I.

5. Klebs, G.: Die Bedingungen der Fortpflanzung bei einigen Algen und Pilzen; Jena, 1896 .

\section{EXPLANATION OF FIGURES IN PLATE XI.}

Illustrating Miss Snow's paper on Pseudo-Pleurococcus.

All figures were drawn with an Abbe camera. In all figures except Fig. I6 a $3 \mathrm{~mm}$. Zeiss apochromatic objective and a No. 6 compensating ocular were used. In Fig. I6 the same ocular was used, and an $8 \mathrm{~mm}$. lens.

$$
\text { Psendo-Pleurococcus botryoides, Nov. sp. }
$$

Figs. $1-6$. Different stages found on bark.

Figs. 7, 8. Development of unicellular stage into filamentous stage.

Figs. 9-I 2. Development of unicellular stage into parenchymatous stage.

Fig. I3. Development of filamentous stage into parenchymatous stage.

Figs. I4, I 5. Development of parenchymatous stage into filaments.

Fig. I6. Filamentous stage from liquid medium.

Pseudo-Pleurococcus vulgaris, Nov. sp.

Figs. I7, I8. Clusters with filaments in different stages of development.

Fig. 19. Beginning of transition from filamentous to parenchymatous and unicellular stages. 


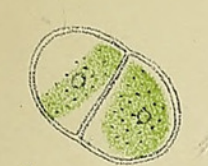

1.

2<smiles></smiles>

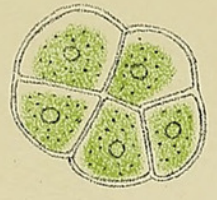

3

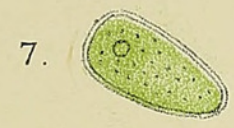

(a)

6.
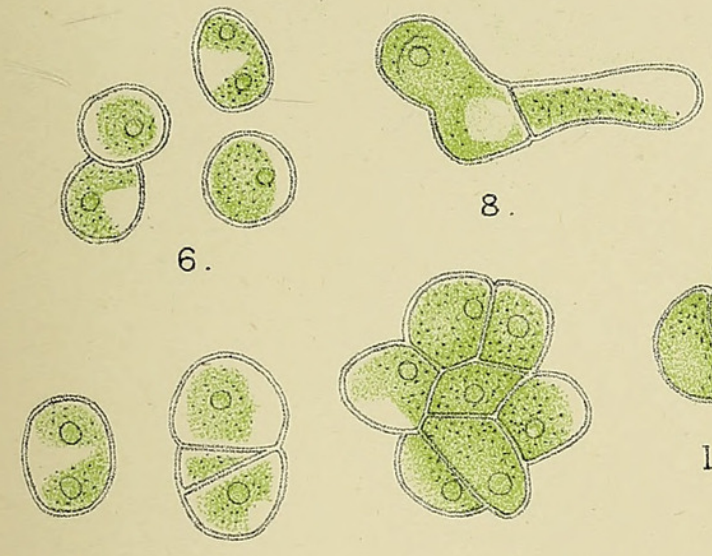

4.

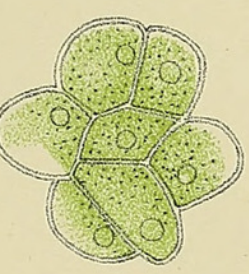

11

10.

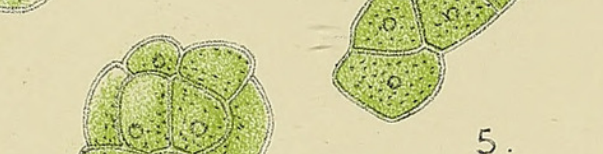

5

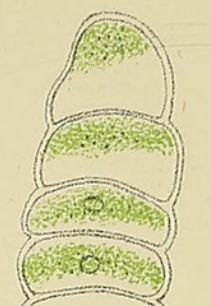
(20.)

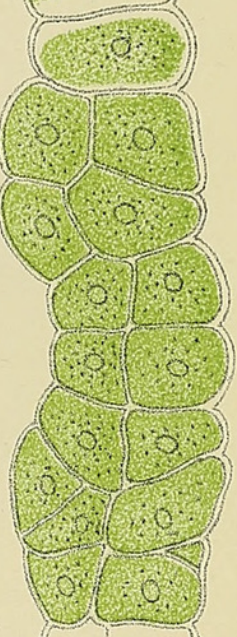

13.

12.

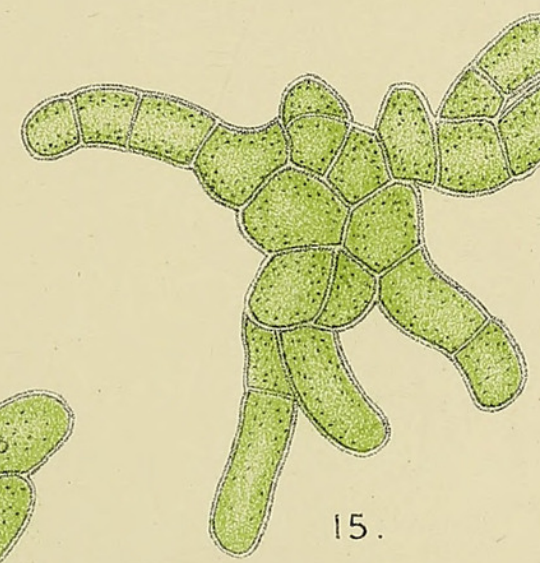

15.
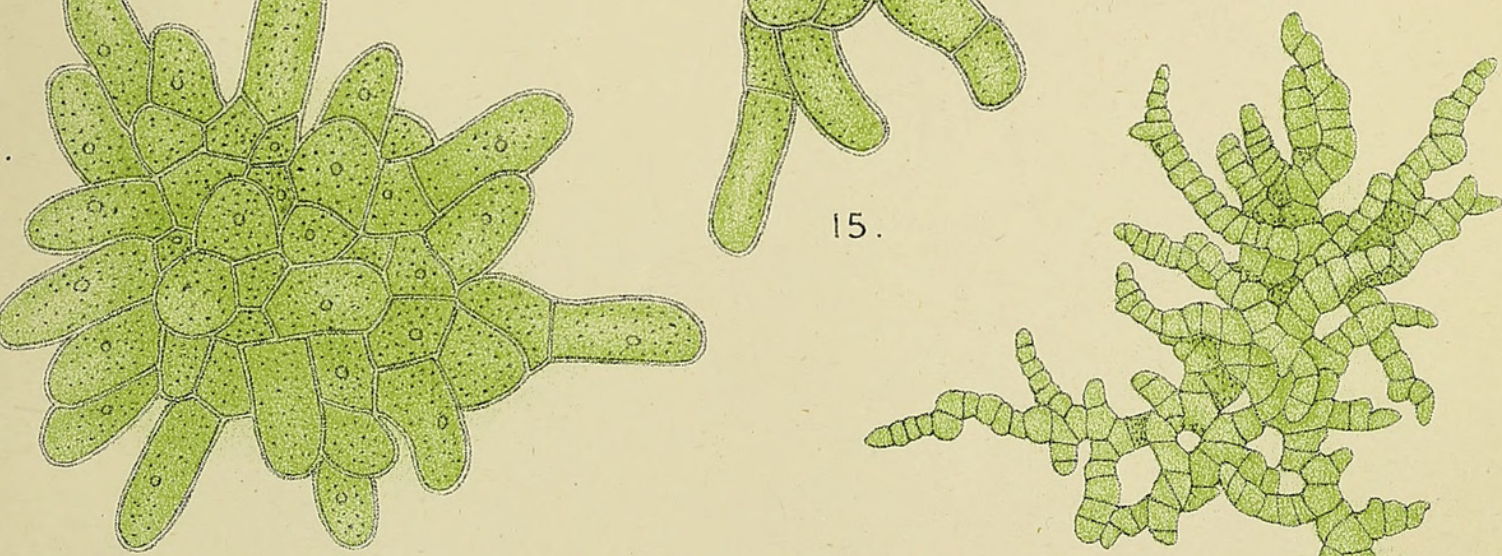

(a)

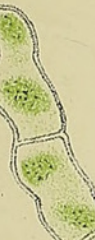

17.

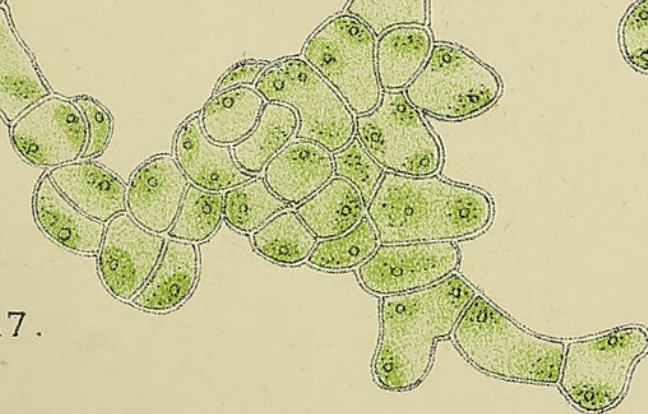

16

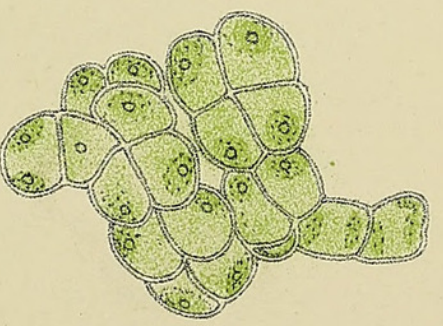

18.

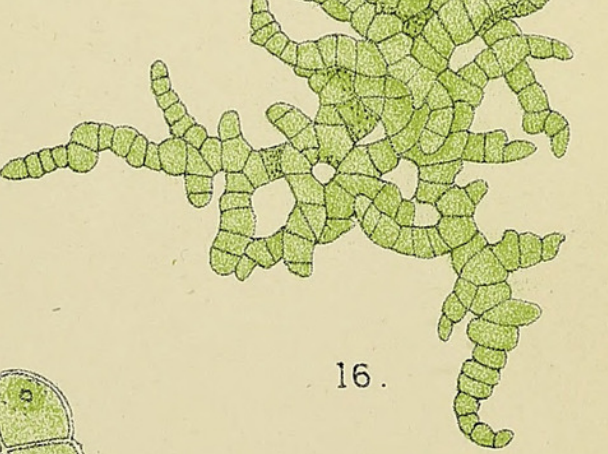

19.

Snow del. 


\section{$2 \mathrm{BHL}$ Biodiversity Heritage Library}

Snow, Julia W . 1899. "Pseudo-pleurococcus, nov. gen." Annals of botany 13, 189-195. https://doi.org/10.1093/oxfordjournals.aob.a088729.

View This Item Online: https://www.biodiversitylibrary.org/item/232524

DOI: https://doi.org/10.1093/oxfordjournals.aob.a088729

Permalink: https://www.biodiversitylibrary.org/partpdf/318535

\section{Holding Institution}

Smithsonian Libraries

\section{Sponsored by}

Biodiversity Heritage Library

\section{Copyright \& Reuse}

Copyright Status: Not in copyright. The BHL knows of no copyright restrictions on this item.

This document was created from content at the Biodiversity Heritage Library, the world's largest open access digital library for biodiversity literature and archives. Visit BHL at https://www.biodiversitylibrary.org. 